\title{
Assessment of CES Function Parameters in Oil-Rich CIS Countries
}

\author{
Yadulla Hasanli ${ }^{1,2}$, Turac Musayev ${ }^{3, *}$, Gunay Rahimli ${ }^{4}$, Simrah Ismayilova ${ }^{3,5}$ \\ ${ }^{1}$ Director of the Scientific-Research Institute of Economic Studies, UNEC, Azerbaijan \\ ${ }^{2} \mathrm{Head}$ of Laboratory of Modeling of Social and Economic Processes, Institute of Control Systems, ANAS, Azerbaijan \\ ${ }^{3}$ Department of Mathematical Software of Economical Researches, Institute of Economics, ANAS, Azerbaijan \\ ${ }^{4} \mathrm{PhD}$ Student, UNEC, Azerbaijan \\ ${ }^{5}$ Laboratory of Modeling of Social and Economic Processes, Institute of Control Systems, ANAS, Azerbaijan
}

Received October 4, 2020; Revised January 12, 2021; Accepted January 22, 2021

\section{Cite This Paper in the following Citation Styles}

(a): [1] Yadulla Hasanli, Turac Musayev, Gunay Rahimli, Simrah Ismayilova , "Assessment of CES Function Parameters in Oil-Rich CIS Countries," Universal Journal of Accounting and Finance, Vol. 9, No. 2, pp. 262 - 266, 2021. DOI: 10.13189/ujaf.2021.090216.

(b): Yadulla Hasanli, Turac Musayev, Gunay Rahimli, Simrah Ismayilova (2021). Assessment of CES Function Parameters in Oil-Rich CIS Countries. Universal Journal of Accounting and Finance, 9(2), 262 - 266. DOI: 10.13189/ ujaf.2021.090216.

Copyright $\odot 2021$ by authors, all rights reserved. Authors agree that this article remains permanently open access under the terms of the Creative Commons Attribution License 4.0 International License

\begin{abstract}
The article analyses balance between the capital and labor market in the CIS countries rich in hydrocarbon resources - Azerbaijan, Kazakhstan and Russia. For this purpose, the impact of capital (fixed assets) and labor (employed population) on the production volume (on GDP) was estimated based on the relevant statistical data from these countries using production function analysis. The parameters of CES production function were determined in the Mathcad system by the nonlinear least-squares method. The subject of the research has enhanced relevance due to the lack of extensive research of the problem posed in the oil and gas-rich countries of the CIS, and the research evaluates the balance between capital and labor markets for the first time in resource-abundant countries. From the results, it can be seen that for each of these three countries the distribution coefficient for capital is significantly higher than that for the labor factor. This means that there is an excess of capital that cannot be started. This is typical for the countries rich in natural resources. The main reason for this process is the complex structure of increasing capital with oil revenues and low level of specialization of the existing labor force to launch this capital. Moreover, according to the results obtained from the CES production function, the substitute elasticity coefficient in oil-rich countries of the CIS is less than one. The study summarizes the current problem as an imbalance between the capital (fixed assets created using modern
\end{abstract}

technology) and the labor market (labor to leverage key assets using potential opportunities). Based on the analysis, the results obtained from modeling is formulated and scientifically grounded recommendations have been provided for the improvement of education and its quality in these three countries, especially in Russia and Azerbaijan.

Keywords Constant Elasticity of Substitution, Production Function, Capital, Specialized Labor Force

\section{Introduction}

There is a historical experience of the existence of certain problems in the field of sustainable development mainly in countries with rich hydrocarbon resources. Numerous studies and cross-country analysis carried out in this direction suggest that countries abundant in natural resources appear to grow at a slower pace $[2,3,8,28]$. The expression "resource curse" is used to characterize the economies of such countries and one of the popular explanation for this curse is called the "Dutch disease" [25, 26]. However, there is also a number of case studies which try to offer proofs that the negative effect of abundant resources is not always the case $[6,19]$. These studies and 
positive examples of some countries rich in natural resources indicate that using revenues derived from the exploitation of natural resources effectively can actually help to achieve long-term sustainable development of the country. Having considered Public spending on education indirectly affects economic growth by causing the growth of a well-educated population [7, 27], using these revenues to increase skilled workforce can have positive impact on economic growth. However, generally in most countries there is a problem related to the cost of capital and its structure [31, 32]. Especially, in resource-rich countries, revenues raised from natural resources is usually channeled into imports of difficult technological products, while the lack of adequate labor that could leverage this capital has led to a decrease in elasticity of substitution of capital and labor. From this point of view, we used production function analysis to evaluate the share of capital and labor in total output.

The evaluation of production functions is of particular importance in assessing economic growth. Production functions can be used for various purposes: system performance can be evaluated using production functions; the possibility of replacing one of the factors of production by another and the result of substitution; the impact of production scale on its efficiency; the impact of management and technical innovation on the production process. Although CES and Cobb-Douglas production functions are based on neoclassical theory, there are significant differences between the two functions. The elasticity of substitution is a measure of the fact that one factor can be replaced by another - the replacement of capital in a production function through labor or vice versa. The possibility of interchangeability of production factors under the condition of a constant production volume makes it possible to combine existing production factors in different ways. The elasticity of substitution in the Cobb-Douglas production function is assumed to be equal to one, while in the CES production function it is estimated arbitrarily. The elasticity of substitution in the Cobb-Douglas production function is assumed to be equal to one, while in the CES production function it is constant $(\sigma>0)$. If the elasticity of capital and labor substitution in the object under consideration is not equal to one, the calculated parameter estimates will reflect the situation incorrectly. To eliminate this discrepancy, it is necessary to estimate the parameters of CES production function and calculate the corresponding coefficient of elasticity of substitution. If the coefficient of elasticity is close to one, the parameters will coincide with the parameters of the Cobb-Douglas production function [24]. Arrow [1] and other economists who used CES for the first time, based on data from 1949-1955, estimated 19 industries in different countries using the least squares method. The results showed that the elasticity of substitution is not always equal to one, as indicated in the Cobb-Douglas production function. Since then, numerous studies have been conducted with the CES production function. Using the least squares method $[1,4,9,10,16,18,23,29,33]$ evaluated CES function for different countries, different periods and different sectors. Among these studies, [17] play a special role. Thus, Kmenta [17] argued that the assumption of constant profitability from the scale of [1] should be changed and added a scale parameter to the production function. Based on the scale parameter, it can be determined that the production function is stable, increasing or decreasing. In addition, Kmenta [17] stated that it would be advisable to use a nonlinear least squares method when evaluating the CES production function. [21] investigated the approval of the Kmenta by the Monte Carlo method. The results showed that the Kmenta procedure, in general, did not give reliable results in evaluating the elasticity of substitution, but the assessment of the scale of profitability was correct. [12, 13, 14, 15] studied the parameters of the CES production function according to the statistical data of Azerbaijan and found that the elasticity of the substitution of capital and labor in the 90s was more than one, in the early 2000s it is very close to one, and after 2010 it is less than one. Different types and forms of production functions (Cobb-Douglas (CD), CES, VES, translog, etc.), their advantages and disadvantages, a comparative analysis of the results obtained by scientists (It began with the introduction of the Cobb-Douglas function in 1928 and covers the period up to 2017) in different periods was very extensively reviewed in the article [30]. In [12, 13, 14, 15], the parameters of the CES production function were studied according to the statistical data of Azerbaijan and found that the elasticity of the substitution of capital and labor in the 90s was more than one, in the early 2000s it was very close to one, and after 2010 it was less than one.

In this study, based on the relevant statistical data from three countries of the CIS (Commonwealth of Independent States) - Azerbaijan, Russia and Kazakhstan, the parameters of the production function of CES (Constant Elasticity Substitution) were determined in the Mathcad system by the nonlinear least squares method. The main common feature of these three CIS countries is that they are rich in natural resources and that these countries have a high share of oil revenues in GDP. Analysis of the calculated parameters shows that the elasticity of substitution (s) of labor and capital for Azerbaijan and Russia was less than one, and for Kazakhstan close to one.

\section{Method}

It is known that production functions have several forms. Among these functions based on the neoclassical theory, the CES function (constant elasticity of substitution) has a more general character. CES production function firstly was introduced by Arrow, Chenery, Minhas and Solow in 1961 in the article "Capital-Labor Substitution and 
Economic Efficiency" [1]. The generalized form of this function is as follows:

$$
Y=A_{0} \cdot\left(\delta K^{-p}+(1-\delta) L^{-p}\right)^{-\frac{v}{p}}
$$

where Y - Gross Domestic Product, K - capital, L is for labor (labor force). According to Hicks, taking into account technical progress, CES production function is written as follows:

$$
Y=A_{0} \cdot e^{\lambda t}\left(\delta K^{-p}+(1-\delta) L^{-p}\right)^{-\frac{v}{p}}
$$

where $e(e \approx 2.72)$ is the Euler number (irrational number); $\mathrm{t}$ is the time indicator.

It is necessary to calculate the following parameters to evaluate this function. $A_{0}-$ is a scale coefficient $\left(A_{0}>0\right)$ which is estimated depending on the unit of measure of other indicators. For example, if the variables are given as percentages, then this indicator characterizes the intensity of production and fluctuates near to one. $\delta-$ is distribution coefficient, $v-$ is the degree of homogeneity $(v>0), \lambda-$ is the parameter characterizing the level of technical progress, $\rho$-is parameter $(\rho \geq-1)$ to calculate the coefficient of substitution elasticity $(\sigma)$.

$$
\sigma=\frac{1}{1+\rho}
$$

As in the case of the Cobb-Douglas production function, also in the CES function, the rate of limit substitution of factors $\mathrm{K}$ and $\mathrm{L}$ is decreasing. Under the condition of a constant volume of production, the rate of substitution of capital by the labor factor is equal to the necessary capital to compensate each unit of labor. The elasticity of substitution $\sigma$ for $Y=F(K, L)$ is calculated as follows:

$$
\begin{gathered}
\sigma_{K L}=-\frac{d \ln (K / L)}{d \ln \left(\frac{M Y_{K}}{M Y_{L}}\right)} \\
\frac{\partial F}{\partial K} d K+\frac{\partial F}{\partial L}=0
\end{gathered}
$$

In open form the equation can be written as follows:

$$
M Y_{K} d K+M Y_{L} d L=0
$$

where, $M Y_{K}$ and $M Y_{L}$ accordingly, are the marginal rate of replacement of production (GDP) from capital and labor.

$$
\begin{gathered}
M Y_{K}=\frac{\partial F}{\partial K} \\
M Y_{L}=\frac{\partial F}{\partial L}
\end{gathered}
$$

Even after logging, the CES function remains non-linear with respect to the parameters. Therefore, to estimate the parameters of this production function, the method of nonlinear least squares is used [34]. At this time, the parameters are found by approximate numerical methods the optimal method of approximation. These methods include the Marquardt method [22], which is a modification of the Newton-Gauss method [5], the LSM by Powelov, the Haybred method, and the Levenberg method [20].

We estimated the parameters of the CES production function for Azerbaijan, Russia and Kazakhstan using the World Bank database, by applying the Marquardt method on MathCat software. First, the statistical characteristics of the parameters were analyzed, and then a comparative analysis of the results with the results was carried out.

\section{Findings}

Speaking about the sustainable development of countries rich in natural resources, it is impossible not to take into account the impact of natural resources on economic development. In particular, revenues from fuel can be a significant level of public revenues. In the ranking, the share of oil revenues in GDP compiled by The Global Economy, Azerbaijan is among the top ten countries(https://www.theglobaleconomy.com/rankings/Oil_ revenue/).

This figure is $17.87 \%$ for Azerbaijan, $10.19 \%$ for Kazakhstan and $6.43 \%$ for Russia. Among world exporters of crude oil in 2018, Russia (11.5\%) is second only to Saudi Arabia (15.9\%) (http://www.worldstopexports.com/worlds-top-oil-exports -country/).

It should be noted that the indexation was carried out considering the corresponding deflator to reflect the collected statistical data on the economic performance of the three countries in real terms.

Table 1. Statistics for Azerbaijan

\begin{tabular}{cccc}
\hline Years & $\begin{array}{c}\text { GDP (current } \\
\text { million USD) }\end{array}$ & $\begin{array}{c}\text { Gross fixed } \\
\text { capital (current } \\
\text { million USD) }\end{array}$ & $\begin{array}{c}\text { Labor force } \\
\text { (total) }\end{array}$ \\
\hline 2004 & 8,680 & & 3794531 \\
2005 & 13,246 & 5,009 & 3888448 \\
2006 & 20,983 & 5,472 & 3978833 \\
2007 & 33,050 & 6,232 & 4077049 \\
2008 & 48,852 & 7,073 & 4218774 \\
2009 & 44,291 & 9,076 & 4358813 \\
2010 & 52,902 & 8,335 & 4454608 \\
2011 & 65,951 & 9,610 & 4542765 \\
2012 & 69,683 & $13,30715,647$ & 4626294 \\
2013 & 74,164 & $19,12920,639$ & 4700437 \\
2014 & 75,244 & 14,768 & 4788222 \\
2015 & 53,074 & 9,480 & 4873418 \\
2016 & 37,867 & 9,733 & 4966648 \\
2017 & 40,747 & 9,75 & 5032491 \\
2018 & 47,113 & 9,314 & 5091052 \\
2019 & 48,048 & & 5103137 \\
\hline
\end{tabular}

Source: World Bank data (https://data.worldbank.org/indicator)

Based on the indicators 2004-2019 (Table 1) using the Marquardt method, the following results were obtained for the parameters of the CES production function for the economy of Azerbaijan: 


$$
\begin{gathered}
Y=1,034 e^{0,17 t}\left(0,92 K^{-2,38}+0,08 L^{-2,38}\right)^{-0,42} \\
R 2=0,95 \quad D \mathrm{~W}=1,26 \quad \sigma=0,29 \\
\mathrm{~F}=255 \quad \mathrm{p}=0.0001
\end{gathered}
$$

Table 2. Statistics for Russia

\begin{tabular}{cccc}
\hline Years & $\begin{array}{c}\text { GDP (current } \\
\text { million USD) }\end{array}$ & $\begin{array}{c}\text { Gross fixed capital } \\
\text { (current million } \\
\text { USD) }\end{array}$ & $\begin{array}{c}\text { Labor force } \\
\text { (total) }\end{array}$ \\
\hline 2004 & $591,016.69$ & 108,66 & 73630048 \\
2005 & $764,017.10$ & 135,654 & 74185621 \\
2006 & $989,930.54$ & 183,171 & 74501961 \\
2007 & $1,299,705.76$ & 272,877 & 75523314 \\
2008 & $1,660,846.39$ & 370,210 & 76066468 \\
2009 & $1,222,644.28$ & 268,922 & 76118376 \\
2010 & $1,524,917.47$ & 329,769 & 75969251 \\
2011 & $2,051,661.73$ & 440,844 & 76121763 \\
2012 & $2,210,256.98$ & 476,307 & 75909195 \\
2013 & $2,297,128.04$ & 500,221 & 75519863 \\
2014 & $2,063,662.67$ & 438,481 & 75327362 \\
2015 & $1,363,705.27$ & 284,319 & 75135866 \\
2016 & $1,282,663.61$ & 281,265 & 75036834 \\
2017 & $1,578,417.21$ & 352,588 & 74308529 \\
2018 & $1,669,583.09$ & 339,781 & 73825998 \\
2019 & $1,699,876.58$ & 367,047 & 73025684 \\
\hline
\end{tabular}

Source: World Bank Data

Based on the indicators 2004-2019 (Table 2) using the Marquardt method, the following results were obtained for the parameters of the CES production function for the economy of Russia:

$$
\begin{gathered}
Y=0.96 e^{-0.007 t}\left(0,98 K^{-1.9}+0,02 L^{-1.9}\right)^{-0.53} \\
R 2=0,98 \quad D \mathrm{~W}=1.5 \quad \sigma=0,34 \\
\mathrm{~F}=1070.8 \quad \mathrm{p}=0.0001
\end{gathered}
$$

Table 3. Statistics for Kazakhstan

\begin{tabular}{cccc}
\hline Years & $\begin{array}{c}\text { GDP (current } \\
\text { million USD) }\end{array}$ & $\begin{array}{c}\text { Gross fixed } \\
\text { capital (current } \\
\text { million USD) }\end{array}$ & $\begin{array}{c}\text { Labor force } \\
\text { (total) }\end{array}$ \\
\hline 2004 & $43,151.65$ & 10,824 & 7806829 \\
2005 & $57,123.67$ & 15,974 & 7951776 \\
2006 & $81,003.88$ & $24,46231,473$ & 8080705 \\
2007 & $104,849.89$ & 35,817 & 8226662 \\
2008 & $133,441.61$ & 32,046 & 8382549 \\
2009 & $115,308.66$ & 36,016 & 8573022 \\
2010 & $148,047.35$ & 41,347 & 8719779 \\
2011 & $192,626.51$ & 47,430 & 8806519 \\
2012 & $207,998.57$ & 51,781 & 8887384 \\
2013 & $236,634.55$ & 47,728 & 8961806 \\
2014 & $221,415.57$ & 42,191 & 9050189 \\
2015 & $184,388.43$ & 31,189 & 9109811 \\
2016 & $137,278.32$ & 35,651 & 9172043 \\
2017 & $162,886.87$ & 37,979 & 9222689 \\
2018 & $179,339.99$ & 41,830 & 9030838 \\
2019 & $180,161.74$ & & 9063070 \\
\hline
\end{tabular}

Source: World Bank data

Based on the indicators 2004-2019 (Table 3) using the Marquardt method, the following results were obtained for the parameters of the CES production function for the economy of Kazakhstan:

$$
\begin{gathered}
Y=0.99 e^{-0.024 t}\left(0,81 K^{-0.365}+0,19 L^{-0.365}\right)^{-2.74} \\
R 2=0,99 \quad D \mathrm{~W}=2.86 \quad \sigma=0,73 \\
\mathrm{~F}=4302.1 \quad \mathrm{p}=0.0001
\end{gathered}
$$

\section{Results, Conclusions and Recommendations}

The results show an imbalance between the capital and the labor markets and the deterioration of disequilibrium compared with previous periods.

Table 4. Parameters of CES

\begin{tabular}{ccccccc}
\hline Years & $\sigma$ & $\delta \mathrm{K}$ & $(1-\delta) \mathrm{L}$ & $\mathrm{A}_{0}$ & $\rho$ & $\lambda$ \\
\hline Azerbaijan & 0,29 & 0,92 & 0,08 & 1,034 & 2,38 & 0,17 \\
Russia & 0,34 & 0,98 & 0,02 & 0,959 & 0,365 & -0.01 \\
Kazakhstan & 0,73 & 0,81 & 0,19 & 0,99 & 1,967 & $-0,02$ \\
\hline
\end{tabular}

From the results, it can be seen that for each of these three countries the distribution coefficient for capital is significantly higher than that for the labor factor. This means that there is an excess of capital that cannot be started. This is typical for the countries rich in natural resources. The main reason for this process is the complex structure of increasing capital with oil revenues and low level of specialization of the existing labor force to launch this capital. So, the imbalance between education and capital is obvious. On the other hand, capital is more mobile than labor. The rapid import of modern capital created using high-tech, innovation and nanotechnology creates a shortage of qualified personnel to mobilize this capital. By directing this free capital to improving the quality of science and education, increasing the level of professionalism of the existing labor force, one can increase the productivity of using new technologies [11]. Investment into knowledge economy and human capital leads to increased output in the economy.

In addition, the coefficient of elasticity of substitution, estimated by the CES production function, is significantly less than one for Azerbaijan and Russia and close to one for Kazakhstan. The study once again confirms that the assessment of the economies of countries with specific features (rich in natural resources) with the Cobb-Douglas production function may not give the best result.

\section{REFERENCES}

[1] Arrow K.J Chenery H.B. Minhas B.S. \& Solow R.M. (1961). Capital-labor substitution and economic efficiency. The Review of Economics and Statistics, 43(3), pp. 225-250.

[2] Auty, R. (1990). Resource-based industrialization: Sowing the oil in eight developing countries. Oxford: Oxford University Press 
[3] Auty, R. (2001). Resource Abundance and Economic Development. Oxford: Oxford University Press.

[4] Bell, F. (1965). A note on the empirical estimation of the CES production function with the use of capital data. The Review of Economics and Statistics, 47(3), pp. 328-30.

[5] Björck, A. (1996). Numerical methods for least squares problems. Philadelphia: SIAM. Retrieved from ISBN 0-89871-360-9

[6] Brunnschweiler, C. N. (2008). Cursing the blessings? Natural resource abundance, institutions, and economic growth. World development, 36(3), 399-419.

[7] Cooray, A. (2010). The Role of Education in Economic Growth. Departament of Economics, University of Wollongong, Working Paper 14-10. Retrieved from http://ro.uow.edu.au/commwkpapers/249

[8] Davis, G. (1995). Learning to love the Dutch disease: Evidence from the mineral economics. World Development 23(10), 1765-1779.

[9] Desai, P. (1976). The production function and technical change in Postwar Soviet Industry: A reexnamination. The American Economic Review, 66(3), pp. 372-381.

[10] Ferguson, C. (1965). Time-series production functions and technological progress in American manufacturing industry. Journal of Political Economy, 73(2), pp. 135-147.

[11] Gylfason, T. (2001). Natural Recources, Education and Economic Development. Europian Economic Review, 847-859. doi:10.1016/S0014-2921(01)00127-1

[12] Hasanli, Y. \& Hasanov, R. (2002). Application of Mathematical Methods in Economic Research. Baku: Elm.

[13] Hasanli, Y. (1998). CES production function and its estimation (in Azerbaijan). Scientific news of Azerbaijan National Academy of Sciences, 6(Physico-Technical and Mathematical sciences), ss. 57-60.

[14] Hasanli, Y. (2013). The evaluation of mutual substitution elasticity of capital and labor factors by application CES function for economy of Azerbaijan. The Journal of Economic Sciences: Theory and Practice, 70(19), 77-96.

[15] Imanov, G. Hasanli, Y. (2001). Socio-economic models of Azerbaijan economy. Macroeconomic analysis. Baku, Azerbaijan: Elm.

[16] Kemfert, C. (1998). Estimated substitution elasticities of a nested CES production function approach for Germany. Energy Economics, 20(3), pp. 249-264.

[17] Kmenta, J. (1967). On the estimation of the CES production function. International Economic Review, 8, pp. 180-189.

[18] Kurz M. \& Manne A.S. (1963). Engineering estimates of capital-labor in metal machining. The American Economic Review, 53(4), pp. 662-681.

[19] Lederman, D., \& Maloney, W. F. (2007). Neither curse nor destiny: Introduction to natural resources and development.
Natural Resources, 1, 1-396

[20] Levenberg, K. (1994). A Method for the Solution of Certain Mom-Linear Problems in Least Squares. Quarterly of Applied mathematics, 2(2), 164-168. doi:10.1090/qam/10666

[21] Maddala, G. \&. (1967). Estimation of returns to scale and the elasticity of substitution. Journal of the Econometric Society, 35(3/4), pp. 419-423.

[22] Marquardt, D. (1963). An Algoritm for Least_Squares Estimation of Nonlinear parameters. SIAM Journal on Applied Mathematics, 11(2), 431-441. doi:10.1137.0111030

[23] Mattieu, L., Gian Luigi Mazzi, Paola Monperrus-Veroni, Frederic Reyne. (2009). A new production function estimate of the euro area output gap. Journal of Forecasting. doi:https://doi.org/10.1002/for.1157

[24] Miller, E. (2008, June). An Assessment of CES and Cobb-Douglas Production Functions. Congressional Budget Office.

[25] Papyrakis E., G. R. (2004). The Resource Curse Hypothesis and its Transmission Channels. Journal of Comparative Economics, 32(1), 181-193.

[26] Polterovich V., P. V. (2008). Mechanisms of resource curse, economic policy and growth. Moscow: New Economic School.

[27] Romer, P. M. (1990). Endogenous Technological Change. Journal of Political Economy, 71-102.

[28] Sachs, J., Warner, A.W. (1995). Natural Resource Abundance and Economic Growth. NBER Working Paper No. 5398

[29] Sato, R. (1970). The estimation of biased technical progress and the production function. International Economic Review, 11(2), pp. 179-208.

[30] Songu, M. \& Sarac Elmas, F. (2017). Cobb-Duglas, CES, VES ve Translog Üretim Fonksiyonlarının Tahminleri Üzerine Genel bir Değerlendirme. Bulletin of Economic Theory and Analysis, 235-278.

[31] Yang, H. Meysami, M. Meisami, A. (2017). A rising market and capital structure decision. Universal Journal of Accounting and Finance, 5(4), pp. 102-108. DOI: 10.13189/ujaf.2017.050404

[32] Yu, H. Tsai, B. Ma, B. (2019). Information Transparency, Debt and the Cost of Equity Capital: Evidence from China. Universal Journal of Accounting and Finance, 7(3), pp. 76-83. DOI: 10.13189/ujaf.2019.070302

[33] Zarembka, P. (1970). On the empirical relevance of the CES production function. The Review of Economics and statistics, 52(1), pp. 47-53.

[34] Кубанива, М. Табата, М. Табата,С. Хасэбэ, Ю. (1991). Математическая экономика на персональном компьютере: пер. с японского. (М. Кубанива, Ред.) Москва: Финансы и статистика. 